\title{
International Journal of Asian Studies
}

Published in association with the Institute for Advanced

Studies on Asia, University of Tokyo

\section{Editor-in-Chief}

Takeshi Hamashita, Ryukoku University, Kyoto, Japan

\section{Managing Editors}

Robert Chard, University of Tokyo, Japan

Akinobu Kuroda, University of Tokyo, Japan

The International Journal of Asian Studies (IJAS) is an interdisciplinary, English-language forum for research in the social sciences and humanities. IJAS examines Asia on a regional basis, emphasising patterns and tendencies that go beyond the borders of individual countries. While the journal covers all regions of Asia, the primary focus is on eastern Asia, that is, Korea, China, Taiwan, Vietnam and Japan. As well as encouraging contributions from western scholars, IJAS focuses attention on the work of Asian scholars, in order to encourage multi-directional communication across the international Asian studies community. IJAS includes both themed and general issues.

\section{Price information}

is available at: http://journals.cambridge.org/asi

\section{Free email alerts}

Keep up-to-date with new material - sign up at http://journals.cambridge.org/alerts

To subscribe contact Customer Services

\section{in Cambridge:}

Phone +44 (0)1223 326070

Fax $+44(0) 1223325150$

Email journals@cambridge.org

\section{in New York:}

Phone +1 (845) 3537500

Fax +1 (845) 3534141

Email

subscriptions_newyork@cambridge.org 


\section{The China Quarterly}

Published for the School of Oriental and African Studies

\section{Editor}

Chris Bramall, School of Oriental and African Studies, UK

The China Quarterly is the leading scholarly journal in its field, covering all aspects of contemporary China including Taiwan. Its interdisciplinary approach covers a range of subjects including anthropology/sociology, literature and the arts, business/economics, geography, history, international affairs, law, and politics. Edited to rigorous standards by scholars of the highest repute, the journal publishes high-quality, authoritative research, keeping readers up to date with events in China. International in scholarship, The China Quarterly provides readers with historical perspectives, indepth analyses, and a deeper understanding of China and Chinese culture. In addition to major articles, each issue also contains a comprehensive Book Review section.

\section{Price information}

is available at: http://journals.cambridge.org/cqy

\section{Free email alerts}

Keep up-to-date with new material - sign up at http://journals.cambridge.org/alerts

To subscribe contact Customer Services

\section{in Cambridge:}

Phone +44 (0)1223 326070

Fax +44 (0)1223 325150

Email journals@cambridge.org

\section{in New York:}

Phone +1 (845) 3537500

Fax +1 (845) 3534141

Email

subscriptions_newyork@cambridge.org 


\section{CAMBRIDGE JOURNALS}

Journal of the Royal Asiatic Society

Published for the Royal Asiatic Society of Great Britain and Ireland

\section{Editor}

Sarah Ansari, University of London, UK

The Journal of the Royal Asiatic Society is distinguished by its longevity and also by its consistency in providing a forum for scholarship of the highest quality on South Asia, the Middle East (together with North Africa and Ethiopia), Central Asia, East Asia and South-East Asia since 1834. It publishes articles on history, archaeology, literature, language, religion and art, and also reviews of newly published books in these fields.

\section{Price information}

is available at: http://journals.cambridge.org/jra

\section{Free email alerts}

Keep up-to-date with new material - sign up at http://journals.cambridge.org/alerts

To subscribe contact Customer Services

\section{in Cambridge:}

Phone $+44(0) 1223326070$

$\mathrm{Fax}+44(0) 1223325150$

Email journals@cambridge.org

\section{in New York:}

Phone +1 (845) 3537500

Fax $+1(845) 3534141$

Email

subscriptions_newyork@cambridge.org 


\section{Medical History}

An International Journal for the History of Medicine and Related Sciences

\section{Editor}

Sanjoy Bhattacharya, University of York, UK

Medical History is a refereed journal devoted to all aspects of the history of medicine, health and related sciences, with the goal of broadening and deepening the understanding of the field, in the widest sense, by historical studies of the highest quality. It is associated with the European Association for the History of Medicine and Health, the Asian Society for the History of Medicine, and the World Health Organization's Global Health Histories initiative. The membership of the Editorial Board reflects the commitment to the finest international standards in refereeing of submitted papers and the reviewing of books.

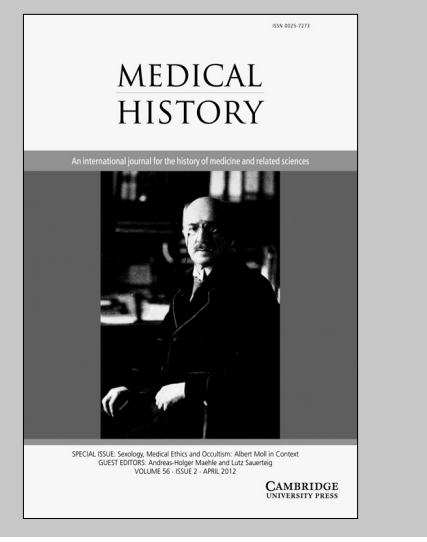

Medical History

is available online at: http://journals.cambridge.org/mdh

To subscribe contact Customer Services

\section{Americas:}

Phone +1 (845) 3537500

Fax +1 (845) 3534141

Email

subscriptions_newyork@cambridge.org

\section{Rest of world:}

Phone +44 (0)1223 326070

Fax +44 (0)1223 325150

Email journals@cambridge.org

\section{Free email alerts}

Keep up-to-date with new material - sign up at

journals.cambridge.org/register 


\section{CAMBRIDGE JOURNALS}

Journal of Southeast Asian Studies

Published for the History Department

National University of Singapore

\section{Editor}

Maurizio Peleggi, National University of Singapore, Singapore

The Journal of Southeast Asian Studies is one of the principal outlets for scholarly articles on Southeast Asia (Brunei, Cambodia, Indonesia, Laos, Malaysia, Myanmar, the Philippines, East Timor, Singapore, Thailand and Vietnam). Embracing a wide range of academic disciplines in the humanities and social sciences, the journal publishes manuscripts oriented toward a scholarly readership but written to be accessible to non-specialists. The extensive book review section includes works in Southeast Asian languages.

\section{Price information}

is available at: http://journals.cambridge.org/sea

\section{Free email alerts}

Keep up-to-date with new material - sign up at http://journals.cambridge.org/alerts

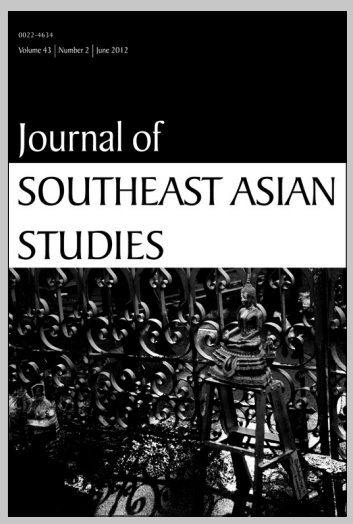

Journal of Southeast Asian Studies is available online at: http://journals.cambridge.org/sea

To subscribe contact Customer Services

\section{in Cambridge:}

Phone +44 (0) 1223326070

$\mathrm{Fax}+44$ (0)1223 325150

Email journals@cambridge.org

\section{in New York:}

Phone +1 (845) 3537500

Fax +1 (845) 3534141

Email

subscriptions_newyork@cambridge.org 


\section{CAMBRIDGE JDUNALS}

Cambridge Journals Digital Archive

$>1770-2011$

$>$ Over 220 titles

- From Volume 1

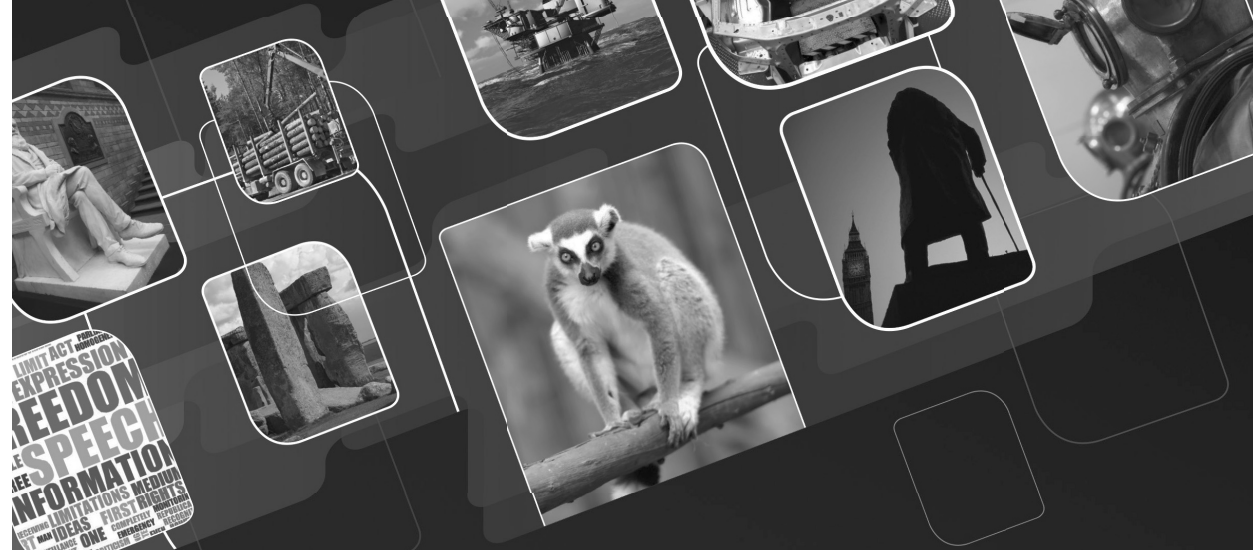

journals.cambridge.org/archives 


\section{Modern Asian Studies}

Modern Asian Studies promotes original, innovative and rigorous research on the history, sociology, anthropology and economics of modern Asia. Covering South Asia, South-East Asia, China, Japan and Korea, the journal is published in six parts each year. It welcomes articles which deploy inter-disciplinary and comparative research methods. Modern Asian Studies specialises in the publication of longer monographic essays based on path-breaking new research; it also carries substantial synoptic essays which illuminate the state of the broad field in fresh ways. Issues of the journal will occasionally contain a forum of articles on related themes. Responses to issues raised in the fora are welcomed by the Editor and will be subject to the usual review procedure. Substantial review articles will be commissioned to discuss important new books. The Book Review Editor also welcomes proposals for such reviews. Unsolicited review articles will be accepted on the basis of peer review. For full details on all submissions, refer to the Instructions for Contributors at http:// journals.cambridge.org/mas/ifc

\section{Submissions}

Modern Asian Studies has moved to online submissions. Papers should be submitted via the following website http://mc.manuscriptcentral.com/ass. If there are any difficulties please contact the editorial office at modern asianstudies@cambridge.org

Submission of an article will be taken to imply that it has not been previously published and that it is not on offer to any other publisher. Authors of articles published in the journal assign copyright to Cambridge University Press (with certain rights reserved) and will receive a copyright assignment form for signature on acceptance of their paper. Authors are responsible for obtaining permission to reproduce any material in which they do not own copyright, to be used in both print and electronic media, and for ensuring that the appropriate acknowledgements are included in their manuscript.

The Editor welcomes expression of all shades of opinion, but responsibility for them rests with their author. The Editorial Board regrets that it is not able to relay reports for articles not accepted for publication.

All correspondence should be addressed to: Dr Joya Chatterji at modernasianstudies@cambridge.org

\section{Text and Manuscript Preparation}

All articles (text and footnotes) must be clearly typed in single spacing throughout, including footnotes. The use of diacritical marks, italics and capital letters should be kept to a minimum. All sources or references should be incorporated as footnotes, cited in full in the first instance, within the body of the text. References repeated in the footnotes should be by author and short title. Spelling, dates, references and footnote numbers should be checked for accuracy.

The title of the article, the author's name, affiliation, full postal address and corresponding email address, should be typed at the beginning of the article. An abstract of between 100 and 250 words summarising the contents of the article should be typed before the main text. Sub headings must be used for long articles. Do not use Roman Numerals to divide papers into sections.

Tables should be clearly laid out and numbered consecutively. Vertical lines between columns should be omitted. All figures and totals should be checked for accuracy.

Figures should be supplied final size as electronic files in either TIFF or EPS format, scanned at a minimum of 320dpi for black and white halftone, or colour artwork, at 1200 dpi for black and white line art, and at $800 \mathrm{dpi}$ for combination artwork (line/halftone). They should be clearly numbered with an accompanying figure legend. Each figure should be cited at least once in the text. The spelling of place names should be consistent with that used in the text.

When an article has been accepted for publication, the author must submit an electronic copy and should ensure that the final manuscript includes the following:

- Full title and short title of no more than 40 characters, including spaces (for running header)

- Author name, affiliation, full postal address and email address

- Abstract of $100-200$ words

- Sub section headings

- All figures and tables (with captions and consecutively numbered)

\section{Proofs}

Authors should note that no substantive alterations or additions can be made to first proofs, so should ensure that their Word Document is thoroughly checked for accuracy before final submission.

\section{Offprints}

Each author will receive a PDF file of his or her published article.

\section{GOPYING}

This journal is registered with the Copyright Clearence Center, 27 Congress St, Salem, Mass. or97o. Organizations in the USA who are also registered with C.C.C. may therefore copy material (beyond the limits permitted by sections I07 and Io8 of US copyright law) subject to payment to C.C.C. of the per-copy fee of \$12.00. This consent does not extend to multiple copying for promotional or commercial purposes. Code 0026-749x/I4 \$12.0o. ISI Tear Sheet Service, 350i Market Street, Philadelphia Pennsylvania I9IO4, USA, is authorized to supply single copies of separate papers for private use only. Organizations authorized by the Copyright Licensing Agency may also copy material subject to the usual conditions. For all other use, permission should be sought from Cambridge or the American Branch of Cambridge University Press.

\section{Advertising}

All advertising enquiries from US, Mexico and Canada please contact the Advertising Coordinator (New York) at usadsales@cambridge.org. All enquiries from the Rest of the World please contact: 
VOLUME 48 PART 1 JANUARY 2014

\section{CONTENTS}

NeILESH Bose: Purba Pakistan Zindabad: Bengali Visions of Pakistan, 1940-1947

UdITI SEN: The Myths Refugees Live By: Memory and history in the making of Bengali refugee identity

DWAIPAYAN SEN: Representation, Education and Agrarian Reform: Jogendranath Mandal and the nature of Scheduled Caste politics, 1937-1943

AMANDA GILBERTSON: A Fine Balance: Negotiating fashion and respectable femininity in middle-class Hyderabad, India

Peter PhILLIMORE: 'That Used to be a Famous Village': Shedding the past in rural north India

SHugE Wel: Beyond the Front Line: China's rivalry with Japan in the English-language press over the Jinan Incident, 1928

NAOKO SHIMAZU: Diplomacy As Theatre: Staging the Bandung Conference of 1955

AleXANDER MorRIson: Twin Imperial Disasters. The invasions of Khiva and Afghanistan in the Russian and British official mind, 1839-1842

ELISABETH MARIKO LEAKE: British India versus the British Empire: The Indian Army and an impasse in imperial defence, circa 1919-39 